\title{
Molecular targets and oxidative stress biomarkers in hepatocellular carcinoma: an overview
}

\author{
Monica Marra', Ignazio M Sordelli ${ }^{2}$, Angela Lombardi ${ }^{1}$, Monica Lamberti ${ }^{3}$, Luciano Tarantino ${ }^{4}$, Aldo Giudice ${ }^{5}$, \\ Paola Stiuso ${ }^{1}$, Alberto Abbruzzese ${ }^{1}$, Rossella Sperlongano ${ }^{2}$, Marina Accardo ${ }^{6}$, Massimo Agresti ${ }^{2}$, Michele Caraglia ${ }^{{ }^{*}}$ \\ and Pasquale Sperlongano ${ }^{2}$
}

\begin{abstract}
Hepatocellular carcinoma (HCC) is a complex and heterogeneous tumor with multiple genetic aberrations. Several molecular pathways involved in the regulation of proliferation and cell death are implicated in the hepatocarcinogenesis. The major etiological factors for HCC are both hepatitis B virus (HBV) and hepatitis C virus infection (HCV).

Continuous oxidative stress, which results from the generation of reactive oxygen species (ROS) by environmental factors or cellular mitochondrial dysfunction, has recently been associated with hepatocarcinogenesis. On the other hand, a distinctive pathological hallmark of HCC is a dramatic down-regulation of oxido-reductive enzymes that constitute the most important free radical scavenger systems represented by catalase, superoxide dismutase and glutathione peroxidase.

The multikinase inhibitor sorafenib represents the most promising target agent that has undergone extensive investigation up to phase III clinical trials in patients with advanced HCC. The combination with other target-based agents could potentiate the clinical benefits obtained by sorafenib alone. In fact, a phase II multicenter study has demonstrated that the combination between sorafenib and octreotide LAR (So.LAR protocol) was active and well tolerated in advanced HCC patients.

The detection of molecular factors predictive of response to anti-cancer agents such as sorafenib and the identification of mechanisms of resistance to anti-cancer agents may probably represent the direction to improve the treatment of HCC.
\end{abstract}

\section{Introduction}

Hepatocellular carcinoma (HCC) is the most common type of primary liver cancer representing the $85 \%$ of liver cancers. Other types of liver cancer include cholangiocarcinoma, which starts in the cells that line the bile duct, angiosarcoma (or haemangiosarcoma), which starts in the blood vessels of the liver, and hepatoblastoma which is very rare and usually affects young children.

HCC accounts for up to $75 \%$ to $85 \%$ of primary liver cancer in the United States (U.S.) [1] and for over 90\% in high-risk areas. It predominantly affect people in developing countries, such as sub-Saharan Africa, China, Taiwan, Korea, or Vietnam [2,3].

\footnotetext{
* Correspondence: michele.caraglia@unina2.it

'Department of Biochemistry and Biophysics, Second University of Naples, Naples, Italy

Full list of author information is available at the end of the article
}

The incidence has been increasing in recent years in the Mediterranean countries, including Italy, where the incidence and mortality rates are at a median frequency compared to other populations, and it represents the seventh cause of death for tumor, with about 5,000 deaths per year [4-6].

Liver cirrhosis is present in about $90 \%$ of HCC [7] mainly caused by chronic infection by hepatitis B (HBV) and $\mathrm{C}(\mathrm{HCV})$ viruses [2,8-12] and/or alcohol assumption.

Race, heavy alcohol use, cigarette smoking, obesity, and mellitus diabetes have also been associated with an increased risk of developing HCC. HCC is now more often associated with HCV, particularly in developed countries. On the other hand, HCC is now decreasing in $\mathrm{HBV}$ endemic countries due to the implementation of

\section{Biomed Central}

(c) 2011 Marra et al; licensee BioMed Central Ltd. This is an Open Access article distributed under the terms of the Creative Commons Attribution License (http://creativecommons.org/licenses/by/2.0), which permits unrestricted use, distribution, and reproduction in any medium, provided the original work is properly cited. 
vaccination programs while it is increasing in cohorts who have been infected with chronic HCV [13-22].

\section{Hepatocarcinogenesis}

The molecular mechanism of hepatocarcinogenesis is very intricated. Cancer cells have defects in regulatory genes that govern normal cell proliferation and homeostasis due to a progressive accumulation of mutations. The alterations in cell physiology that collectively dictate malignant growth are: i) self-sufficiency in growth signals (activation of oncogenes); ii) insensitivity to growth-inhibitory signals (inactivation of anti-oncogenes or tumor suppressor genes); iii) escape from apoptosis; iv) limitless replicative potential; v) neo-angiogenesis and tissue invasion and metastases [23].

In fact, hepatocarcinogenesis is considered a multistep process involving subsequent mutations of genes that control proliferation and/or apoptosis in the hepatocytes subjected to continuous inflammatory and regenerative stimuli, starting from the initial phases of chronic hepatitis and then of liver cirrhosis.

$\mathrm{HCC}$ is associated with, and preceded by, a number of morphologically distinct lesions. The latter are collectively described as 'preneoplastic lesions', and include dysplastic foci and dysplastic nodules. Hepatic nodules in patients with chronic liver diseases are subdivided into regenerative nodules (mono acinus and multi acinus), low-grade dysplastic nodules, high-grade dysplastic nodules, well-differentiated HCC, moderately-differentiated HCC, and poorly-differentiated HCC, in an ascending order of histologic grades, representing a sequence of multistep hepatocarcinogenesis. Accumulation of genetic alterations in the preneoplastic lesions is believed to lead to the development of HCC. Genomic alterations occur randomly, and they accumulate in dysplastic hepatocytes and HCC. Although genetic changes may occur independently of etiologic conditions, some molecular mechanisms have been more frequently related to a specific etiology [24-26].

Under normal physiological conditions, hepatocyte turnover is very low with a half-life estimated at 6 months. However, adult liver cells retain the remarkable capacity to proliferate in response to injury or to the loss of liver mass. Progenitor cells (also referred to as oval cells) do not play a major role in this growth response but, the same 'resting' differentiated hepatocytes re-enter the cell cycle and replicate once or twice during the period of mass restoration before returning to a state of quiescence. In about $40 \%$ of HCC, progenitor cells express peculiar biomarkers (CK-7, CK-19, CD34) associated with a poor prognosis and with disease recurrence [27].

\subsection{Role of HBV and HCV viruses}

$\mathrm{HBV}$ and $\mathrm{HCV}$ viruses can be implicated in the development of HCC in an indirect way, through induction of chronic inflammation, or directly by means of viral proteins or, in the case of HBV, by creation of mutations by integration into the genome of the hepatocyte.

On HCV-infected patients the development of HCC requires about 10 years from the diagnosis of cirrhosis and about 30 years from exposure to HCV [28]. Conversely, the time course of HBV-related carcinogenesis is less predictable since $\mathrm{HCC}$ may precede the occurrence of cirrhosis, particularly with chronic HBV infection in endemic areas [29]

During the 'preneoplastic' phase (chronic hepatitis and cirrhosis), genetic alterations are almost entirely 'quantitative', occurring by epigenetic mechanisms without changes in the structure of genes. In this phase, hepatocytes undergo an intense mitogenic stimulation due to exposure to elevated levels of growth factors, such as insulin-like growth factor (insulin-like growth factor-2, IGF-2), transforming growth factor- $\alpha$ (TGF- $\alpha$ ), interleukin 6 as well as inflammatory cytokines, which may lead to activation of the major signaling pathways involved in cell proliferation and angiogenesis. The enhanced expression of growth factors and cytokines is driven by inflammation, the action of viral proteins and regenerative response to cell loss. The mechanisms whereby these factors affect gene expression include DNA mutations with consequent activation or inactivation of gene promoters [26].

Development of human HCC by viral (HBV and HCV) factors is resumed in Figure 1.

$H B V$ virus

HBV belongs to a family of closely related DNA viruses, called Hepadnaviridae [30]. It specifies a small number of known gene products, including a reverse transcriptase/DNA polymerase (pol), capsid protein (core), envelope (env) proteins (L, M and S) as well as proteins of uncertain function such as ' $\mathrm{X}$ ' and ' $\mathrm{e}$ '. It is classified as para-retrovirus because its replication depends upon reverse transcription of genome-length RNA.

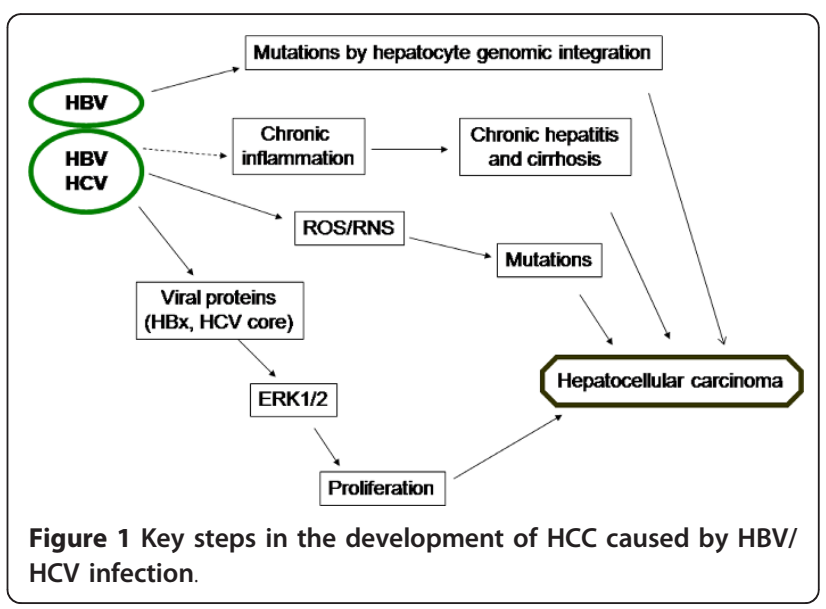


The molecular etiology of HBV-induced HCC remains for the most part unclear. However, the viral protein $\mathrm{X}$ ( $\mathrm{HBx})$ derived by $\mathrm{HBV}$, can directly stimulate the intracellular kinase cascades involved in the regulation of cell proliferation [26,31]. In some HBV-induced HCCs, HBx can inactivate the cellular antioncogene product, p53, which is frequently disabled in HCC [32].

Usually, HBx functions as a transcriptional transactivator of different host genes involved in cellular growth control. HBx transactivates cellular genes involved in cell proliferation control (c-jun, c-fos, c-myc) and growth factor receptors, such as EGF-R, involved in the regulation of cell proliferation and transformation [33]. This transactivation activity appears to involve stimulation of different transcription factors such as CREB (cAMP Responsive Element Binding protein), NFkB (Nuclear Factor kB), AP1 (Activating Protein 1) and NFAT (Nuclear Factor of Activated T Cells) [34,35].

HBV can transform hepatocytes even in the absence of chronic inflammation and cirrhosis, while the role and significance of the inflammation is more important in the development of $\mathrm{HCV}$-associated HCCs. On the other hand, many transcription- and signalling-related genes were upregulated in HBV-HCCs without cirrhosis. The IGF signal pathway seems to play a central role in HBVHCCs, especially when developing from a noncirrhotic liver. A higher number of genes were differently expressed between HBV-HCCs associated or not with cirrhosis.

HBV replication appears to involve heat shock proteins [36] and viral envelope gene transcription may be actually upregulated by endoplasmic reticulum (ER stress) which interrupts protein folding causing accumulation of unfolded or misfolded proteins in ER leading to a cell response that involves mutagenic reactions [37]. Hepatitis B virus X protein $(\mathrm{HBx})$ activates ATF6 and IRE1-XBP1 pathways of unfolded protein response [38].

\section{HCV virus}

Hepatitis $C$ virus is a member of the Flaviviridae family of enveloped, positive-strand RNA viruses [39]. Similar to $\mathrm{HBV}, \mathrm{HCV}$ utilizes the ER as the primary site of genomic replication and virion assembly $[40,41]$. Upon entry and uncoating, the RNA viral genome is translated by ER bound ribosomes into a polyprotein that is cleaved by cellular and viral proteases to generate 10 mature viral gene products, including the core protein that forms the viral capsid, NS3, which has the protease and helicase activity, NS5A, and the viral RNA polymerase NS5B. In addition to the proteins derived from the polyprotein coding sequence, the HCV RNA codes for another protein termed the $\mathrm{F}$ protein or the alternative reading frame protein (ARFP) using an open reading frame that overlaps with the core protein coding sequence $[42,43]$.
The HCV capside core is a multifunctional protein with regulatory functions that affects transcription and cell growth in vitro and in vivo [44].

The HCV core binds to the p53, p73 and pRb tumor suppressor proteins [45-48], but the functional consequences of these interactions have not fully been elucidated. Hepatitis $\mathrm{C}$ virus core protein also modulates the expression of the cyclin-dependent kinase (CDK) inhibitor p21/Waf [49]. Hepatitis $C$ virus core protein is produced as an innate form (amino acids 1-191) that is then processed to produce a mature form (amino acids 1-173). The innate core protein in the cytoplasm increases the amount of p21WAF1 by activating p53, and the mature core protein in the nucleus decreases the amount of p21WAF1 by a p53-independent pathway $[50,51]$.

The ability of HCV core proteins to directly activate the MAP kinase cascade and to prolong its activity in response to mitogenic stimuli may contribute to the neoplastic transformation of $\mathrm{HCV}$ infected liver cells [44]. Recently, it was demonstrated that HCV-infection causes ER-stress, Ca2+ homeostasis deregulation and reactive oxygen species (ROS) production by mitochondria that would lead to apoptosis [52-55].

The pathological alterations caused by HCV are similar to the HBV-related disease; acute and chronic hepatitis, cirrhosis and HCC. HCV is not considered as a directly cytotoxic virus; hepatitis occurs as a result of the reaction of the host immune system against the virus infected cells.

Low number of genes were expressed differently between $\mathrm{HCV}-\mathrm{HCCs}$ associated with and without cirrhosis.

The most effective tool to prevent $\mathrm{HCC}$ is avoidance of the risk factors such as viral infection. An effective vaccine has been available for prevention of new infection with $\mathrm{HBV}$; however, no vaccine exists against $\mathrm{HCV}$ infection.

\section{Molecular biomarkers of HCC pathogenesis}

The carcinogenesis and progression of HCC is a complex multistep process that involves multiple genetic aberrations. The molecular mechanisms involved in development and progression of HCC are still largely unknown. On the other hand, different molecular markers have been considered as prognostic factors for HCC. To deepen the molecular mechanisms underlying $\mathrm{HCC}$ carcinogenesis and progression is important for improving prognosis and treatment strategies.

Several molecular pathways involved in the regulation of proliferation and cell death are implicated in the hepatocarcinogenesis (Figure 2). In fact, experimental studies have shown structural genomic changes in very early stages of hepatocarcinogenesis. Genomic 


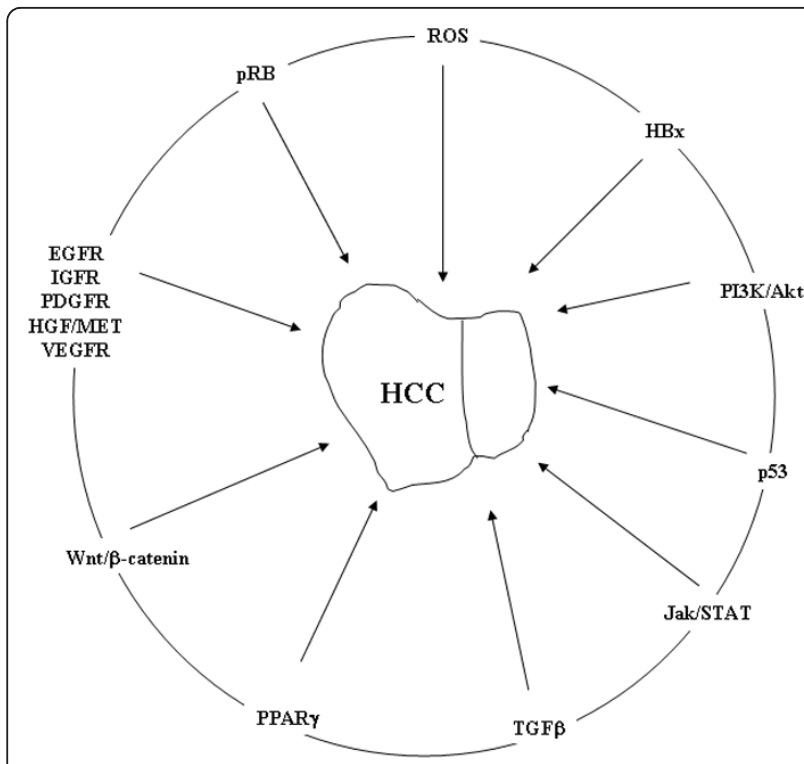

Figure 2 Cellular signaling pathways implicated in HCC

instability, rearrangements and transactivation of Ras and $\beta$-catenin signaling are induced by the integration of HBV into hepatocyte genome $[26,56]$. HCV core protein also upregulates TGF- $\alpha$ and IGF-2 [57-60].

The most common genetic alterations in HCC can be grouped into 3 main routes: i) p53- ii) Wnt-and iii) RB1-dependent pathways [61]

The binding of Wnt proteins to specific Frizzled receptors on the surface of target cells activates distinct intracellular pathways. This results in the accumulation and nuclear localization of the $\beta$-catenin protein characteristic of canonical Wnt pathway activation that targets specific genes including cyclin D1, c-Myc, and survivin, which are critical for cancer development $[62,63]$. In fact, a transgenic mice model suggested that high expression of Wnt-1 could be the major cause for nuclear accumulation of $\beta$-catenin, which subsequently contributes to cmyc/E2F1-driven hepatocarcinogenesis [64]. Clinical studies have reported that abnormal activation of Wnt/ $\beta$ catenin pathway is frequently involved in hepatocarcinogenesis. About 33-67\% of HCC tissues show accumulation of $\beta$-catenin in the cytoplasm and nucleus, whereas no accumulation was observed in the corresponding normal tissues $[65,66]$. In addition, upregulation of upstream elements such as Frizzled receptors was reported to be involved in HCC development and progression $[67,68]$. The activation of $\mathrm{Wnt} / \beta$-catenin signaling was abolished by a knockdown of Frizzled-7 receptor expression by siRNA. More important, a specific Wnt3-Frizzled-7 receptor interaction was observed by co-immunoprecipitation experiments, which suggest that the action of Wnt3 was mediated via Frizzled-7 receptor [69].
In $\mathrm{HCC}$, proteomics results suggested that enhanced Wnt-1 expression associated with NF-kB might be an important mechanism underlying hepatocarcinogenesis [70].

MAPK cascade transduces signals from tyrosine kinase receptors, such as EGFR, IGFR, Platelet-derived growth factor receptor (PDGFR), Hepatocyte growth factor receptor (HGF/MET), and Vascular endothelial growth factor receptor (VEGFR). In this cascade, active Ras (Ras-GTP) triggers the sequential activation of RAF-1, MEK-1/2, and ERK-1/2. The activation/phosphorylation of ERK1/2 allow to enter into the nucleus where transactivates numerous growth-related genes, including cJUN, c-FOS, c-MYC (involved in the proliferation and survival mechanisms), vascular endothelial growth factor (VEGF) and hypoxia-induced factor (HIF-1 $\alpha$ ) that regulates angiogenesis, and HKII (Hexokinase II) [71-73]. The constitutive activation of ERK1/2 can determine an increase of cell proliferation also in absence of growth factor. This condition can lead to tumour progression.

Genes that are components of MAPK cascade, such as Ras-GTP, c-RAF, c-FOS, and c-JUN, may be upregulated in HCC induced in rodents [58,74]. 3-Hydroxy-3methylglutaryl-CoA reductase gene, encoding a key enzyme for de novo synthesis of mevalonate, a precursor of isoprenoid residues necessary for activation of Ras, is upregulated in rat and human liver lesions [75].

Recent studies have shown high levels of active Ras, accompanied by modest/no increase in active RAF-1 and pMEK-1/2, in HCC. This is compatible with the strong induction of the inhibitors of phosphorylation/ activation of RAF-1 and MEK-1/2: disabled homolog 2 (Dab2), and RAF kinase inhibitory protein (RKIP), respectively [73].

Up-regulation of principal mediators of the pathway, $\mathrm{H}$-ras and B-RAF, was detected in $\mathrm{HCC}$ confirming their role in cancer. Different mechanisms account for Ras signaling in $\mathrm{HCC}$, including:

i) H-ras overexpression; ii) DNA copy number gains in B-RAF genomic locus (chromosome 7q34); iii) epigenetic mechanisms involving the methylation of tumor suppressor genes RASSF1A and NORE1A [76].

The Ras-RAF-ERK-dependent pathway is implicated in the molecular pathogenesis of HCC for three reasons: i) Ras protein is activated in the $30 \%$ of cases of $\mathrm{HCC}$ [77]; ii) the over-expression of Raf kinase is in the majority of HCC [78]; iii) several upstream growth factors, such as EGF, VEGF, PDGF, TGF $\alpha$, generally overexpressed in $\mathrm{HCC}$, can activate this pathway binding proper tyrosin kinase receptors [79].

Recently developed technology, such as DNA microarrays and other molecular profiling techniques, has provided new insights into the molecular genetics of HCC $[80,12]$. 
$\mathrm{HCC}$ are classified in metabolic pathways, and the most represented are the Aryl Hydrocarbon receptor signalling (AHR), involved in the activation of the cytosolic aryl hydrocarbon receptor by structurally diverse xenobiotic ligands (including dioxin, and polycyclic or halogenated aromatic hydrocarbons) and mediating their toxic and carcinogenic effects [81] and, protein Ubiquitination pathways, involved in cell-cycle regulation as well as cell death/apoptosis [82] through modification of target proteins.

Moreover, molecular profiling has been successfully used to identify candidate genes for HCC such as genes correlated with tumour progression (p16, SOCS1, PEG10), metastatization (NM23-H1, osteopontin, RhoC, KAI1, MMP14) or recurrence (REL, A20, vimentin, PDGFRA) [83].

\section{Involvement of Oxidative stress in HCC}

Studies of mechanisms of oxidative stress have shown that it activates signaling cascades (including MAPK pathway), which can seriously influence regulation of cell growth and transformation processes [84]. Particularly, MAP kinases may be involved in pathogenesis of some diseases associated with oxidative stress.

It is known that the oxidative stress status has a key role in HCC development and progression.

The most important reactive oxygen species (ROS) derived by molecular oxygen include free oxygen radicals [e.g., superoxide $\left(\mathrm{O}_{2} \bullet-\right)$, hydroxyl radical $\left(\mathrm{OH}^{-}\right)$, nitric oxide (NO) radicals] as well as nonradical ROS [e. g., hydrogen peroxide $\left(\mathrm{H}_{2} \mathrm{O}_{2}\right)$, organic hydroperoxides, and hypochloride].

A low level of ROS is indispensable in several physiologic processes of the cell including proliferation, apoptosis, cell cycle arrest, cell senescence, etc. [85]. However, an increased level of ROS causes oxidative stress and creates a potentially toxic environment to the cells. In normal physiologic condition, a balance between ROS generation and oxidative defences exists in a cell. A significant role is played by endogenous antioxidant enzymes such as superoxide dismutase (SOD), catalase (CAT) that act on $\mathrm{O}_{2} \bullet$ and $\mathrm{H}_{2} \mathrm{O}_{2}$, respectively, and glutathione peroxidase (Gpx1) that uses glutathione as co-substrate. Despite the basal production of radicals is hampered by the anti-oxidant defences, the generation of ROS is amplified in response to various environmental perturbations.

This stressful condition is known to play a major role in cancer development mainly by enhancing DNA damage and by modifying some key cellular processes, such as DNA damage caused primarily by hydroxyl radicals [64], cell proliferation, apoptosis, and cell motility cascades by superoxide radicals and hydrogen peroxides playing an important role in cancer development.
Although extensive or limited damage may trigger cell death, many cells can tolerate and repair the occasional hit from ROS. In the Fruehauf model [86], when the balance tips further in favour of ROS, programmed cell death becomes a near certainty.

Excessive ROS, which the cellular enzymes cannot neutralize, alters the chemical environment within the mitochondria; in fact, the pore protein that forms a channel through the mitochondrial membranes becomes jammed in the open position, allowing cytochrome $c$ to escape into the cytoplasm thus triggering programmed cell death.

The increase of ROS is associated with the increase of the inducible mitochondrial manganese SOD (MnSOD) expression. Elevated serum MnSOD levels have been found in patients with HCC [87] and relatively high values of the enzyme have also been observed in patients with chronic hepatitis and liver cirrhosis. Therefore, it could be hypothesized that during induction of the malignant process in cirrhotic liver, the increase in MnSOD activity can already occur in the precancerous phase.

In cancer biology, $\mathrm{NO}$ can be involved either in promotion or in prevention of tumour occurrence dependently from tumour microenvironment, NO concentration and time of exposure [88]. NO is a product of endothelial cells that binds and activates the guanylate cyclase, which catalyzes the conversion of GTP to the second messenger molecule cyclic GMP (cGMP). Concentrations of NO ranging between 1 and $30 \mathrm{nM}$ produce high levels of cGMP promoting angiogenesis and proliferation of endothelial cells. In these conditions, ERK phosphorylation stimulates the proliferation of endothelial cells. Concentrations of NO ranging between 30 and $100 \mathrm{nM}$ correspond to an increase of proliferative and anti-apoptotic AKT and ERK-dependent pathways in tumour cells [89-91]. This range of concentrations seems to protect tumour cells from apoptosis and enhance angiogenic effects. In these conditions, the molecules activated by NO can be considered as factors correlated to poor prognosis events. On the other hand, higher NO levels (> $300 \mathrm{nM}$ ) promote apoptosis and are responsible for anti-tumour activity. NO levels are influenced also by ROS and, specifically, by superoxide anions that can attenuate the NOmediated pathway. In fact, superoxide anions and ROS, through the scavenging of NO, can lower NO levels favouring its tumour-promoting activity [92]. Accordingly, tumours have high levels of ROS and low levels of SOD.

Similarly to oxidative stress, the expression of nitrosative stress supports the de-regulated synthesis or overproduction of NO and NO-derived products and its toxic physiological consequences [93]. The main source 
of $\mathrm{NO}$ in the mammals is the enzymatic oxidation of Larginine by NO synthases [94]. As ROS, NO may limit oxidative damage by acting as a chain-breaking radical scavenger or may cause damage and kill cells by mechanisms that include inhibition of protein [95] and DNA [96] synthesis, downregulation of antioxidative enzymes [97] and depletion of intracellular GSH [98]. Nitrosative insult may occur in vivo also in pathologies associated with inflammatory processes, neurotoxicity and ischaemia [99].

$\mathrm{NO}$ is able to reduce oxidative injury via several mechanisms. NO reacts with peroxy and oxy radicals generated during the process of lipid peroxidation. The reactions between $\mathrm{NO}$ and these ROS can terminate lipid peroxidation and protect tissues from ROS-induced injuries [100]. Through the Fenton reaction, hydrogen peroxide oxidizes iron (II) and the process generates an extremely reactive intermediate (the hydroxyl radical) which then carries out oxidations of different substrates $\left[\mathrm{H}_{2} \mathrm{O}_{2}+\mathrm{Fe}^{2+} \rightarrow \mathrm{Fe}^{3+}+\mathrm{OH}-+\right.$ hydroxyl radical $\left.(\cdot \mathrm{OH})\right]$. NO prevents hydroxyl radical formation by blocking the predominant iron catalyst in the Fenton reaction. In fact, NO reacts with iron and forms an iron-nitrosyl complex, inhibiting iron's catalytic functions in the Fenton reaction [101].

Treatment of rat hepatocytes with NO induces resistance to $\mathrm{H}_{2} \mathrm{O}_{2}$-induced cell death by induction of the rate-limiting antioxidant enzyme, heme oxygenase ( $\mathrm{HO}$ 1) [102]. In addition, NO prevents the induction of some ROS-induced genes during tissue injury such as early growth response-1 (EGR-1), which activates a number of adhesion molecules and accelerates oxidative tissue injuries [103].

Regulatory events and their alterations depend on the magnitude and duration of the change in ROS or RNS concentration. ROS and RNS normally occur in living tissues at relatively low steady-state levels. The increase in superoxide or NO production leads to a temporary imbalance that forms the basis of redox regulation. The persistent production of abnormally large amounts of ROS or RNS, however, may lead to persistent changes in signal transduction and gene expression, which, in turn, may give rise to pathological conditions [104].

\subsection{Stress and HCC}

Oxidative stress has emerged as a key player in both development and progression of many pathological conditions, including $\mathrm{HCV}$ - and HBV-induced liver diseases.

ER stress is a homeostatic mechanism, that regulates cellular metabolism and protein synthesis in response to perturbations in protein folding and biosynthesis [105]. Moderate ER stress modulates protein synthesis initiation and causes a reduction in cell growth, whereas extreme or prolonged ER stress leads to apoptosis mediated by the activation of the ER-associated caspase 12 [106].

Signaling from ER susceptible to stress is closely related to cell metabolism and intracellular redox status [107]. Changes in cell metabolism can cause an increase of mutation processes including stimulation of cell proliferation and apoptosis [84].

Studies of mechanisms of oxidative stress have shown that the latter activates signaling cascades (including MAP kinase pathway), which can seriously influence regulation of cell growth and transformation processes [84] and may be involved in pathogenesis of some diseases associated with oxidative stress.

Oxidative stress also activates hepatic stellate cells that represent the main connective tissue cells in the liver, involved in formation of extracellular matrix and required for normal growth and differentiation of cells during liver damage. In this case, the stellate cells divide in response to various cytokines, growth factors, and chemokines produced by the damaged liver. Chronic activation of stellate cells in response to oxidative stress induced by viral replication may contribute to fibrogenesis and increase proliferation of hepatocytes chronically infected with $\mathrm{HBV}$ and $\mathrm{HCV}$ that, together with activation of MAP kinases, may induce HCC [108].

The nuclear transcription factor $-\kappa \mathrm{B}(\mathrm{NF}-\kappa \mathrm{B})$ is the major stress-inducible antiapoptotic transcription factor. $\mathrm{NF}-\kappa \mathrm{B}$ activation is associated with cancer, and it has been found to be strongly activated in many types of cancer, including HCC [108].

Moreover, markers of acute intracellular oxidative stress were found elevated in patients with chronic $\mathrm{HCV}$ [109] with accumulation of DNA adduct 8-hydroxydeoxyguanosine [110]. Transgenic mice expressing HCV core protein show an increased accumulation of ROS that correlates with HCC development [111].

The increased generation of ROS and RNS, together with the decreased antioxidant defense, promotes the development and progression of hepatic and extrahepatic complications of HCV infection.

\section{HCC therapeutic opportunities}

Ablative therapies, surgical resection or liver transplantation are the first-line treatment for patients affected by HCC [112,113]. Nonetheless, advanced tumour stage and poor liver function preclude the majority of patients from these surgical interventions [114]. Moreover, transplantation is indicated only for early small HCC, and its application is limited by the availability of liver grafts [115]. Therefore, it is mandatory to develop an effective systemic therapy for patients with advanced HCC.

$\mathrm{HCC}$ is a chemo-resistant tumour and conventional cytotoxic chemotherapy has not provided clinical benefit 
or prolonged survival for patients with advanced HCC [116].

In recent years, emerging insights into the biology and molecular signalling pathways in cancer cells have led to the identification of potential targets for intervention and the advent of promising targeted therapy for the treatment of HCC (Table 1).

\subsection{Erlotinib}

With recent advances in the knowledge of hepato-carcinogenesis, there has been encouraging development in the systemic therapy of advanced HCC patients, and particularly in the therapy based on specific targets ("targeted therapy"). Among the newly identified targets, interesting results have been shown in targeting the epidermal growth factor receptor/human epidermal growth factor receptor 1 (EGFR/HER1) and its ligands EGF and transforming growth factor-alpha (TGF- $\alpha$ ), important in cell proliferation, as well as motility, adhesion, invasion, survival, and angiogenesis $[117,118]$. It has been suggested that hypomethylation of the EGF receptor gene may be associated with the development of HCC [119]. Studies have indicated that EGFR/HER1 is actively expressed in human hepatoma [120]. Different phase II studies of Erlotinib (Tarceva, OSI-774; OSI Pharmaceuticals, Melville, NY), an orally active, potent, selective inhibitor of the EGFR/HER1related tyrosine kinase enzyme were performed in patients with HCC $[121,122]$.

In the study by Philip et al. [121] 3 of 38 patients (9\%) achieved partial responses (PR) and 12 of 38 patients $(32 \%)$ were free of disease progression (PD) at 6 months. In another preliminary report by Thomas et al., [122] 8 of 25 patients $(32 \%)$ achieved a median progression-free survival (PFS) of 4 months.

\subsection{Cetuximab}

Cetuximab, a chimeric monoclonal Ig G1 antibody directed against the EGFR that blocks binding of endogenous EGFR ligands, was recently evaluated in HCC patients who had previously received 1 or 2 lines of systemic chemotherapy regimens. Cetuximab was well tolerated, and through concentrations only mild to moderate hepatic dysfunction were observed. However, there were no tumor responses, and the median PFS was only 1.4 months [123].

In another trial [124] Cetuximab was combined with Gemcitabine and Oxaliplatin chemotherapy (GEMOX regimen) in patients with documented progressive HCC. The confirmed response rate was $20 \%$ and disease stabilization (SD) was obtained in $40 \%$ of patients. On the other hand, the toxicity profile was not neglactable $(60 \%$ of grade 3 or 4 toxicity), although still acceptable.

\subsection{Bevacizumab}

Bevacizumab is a recombinant humanized anti-VEGF monoclonal antibody, thereby inhibiting neo-angiogenesis, tumour growth, paracrine/autocrine growth factor release and metastasis. Bevacizumab, both as a single agent and in combination with other agents, has shown initial encouraging activity in treating advanced HCC. In the study by Siegel et al. [125], among 46 patients enrolled with advanced HCC, single-agent bevacizumab induced a $13 \%$ objective response (OR), while $65 \%$ of the patients had SD.

Bevacizumab and erlotinib combination was also investigated in advanced or metastatic $\mathrm{HCC}$ at phase II trials. This regimen consists of bevacizumab $10 \mathrm{mg} / \mathrm{kg}$ every 14 days and erlotinib $150 \mathrm{mg}$ orally daily, continuously, for 28 -day cycles. Of 40 patients, $62.5 \%$ survived beyond 16 weeks without evidence of progression. Ten

Table 1 Targeted agents in development for HCC

\begin{tabular}{|c|c|c|c|c|c|c|c|}
\hline \multirow[t]{2}{*}{ Agent } & \multicolumn{3}{|c|}{ Anti-angiogenic targets } & \multicolumn{3}{|c|}{ Anti-proliferative targets } & \multirow[t]{2}{*}{ Clinical Development } \\
\hline & VEGF & VEGFR & PDGFR & EGFR & Raf & mTOR & \\
\hline Bevacizumab & $\cdot$ & & & & & & Phase II ongoing \\
\hline Brivanib & & $\cdot$ & & & & & Phase II recruiting \\
\hline Cediranib & & $\cdot$ & & & & & Phase II recruiting \\
\hline Erlotinib & & & & $\cdot$ & & & Phase II complete \\
\hline Gefitinib & & & & $\cdot$ & & & Phase II complete \\
\hline Cetuximab & & & & $\cdot$ & & & Phase II complete \\
\hline Lapatinib & & & & $\cdot$ & & & Phase II ongoing \\
\hline RAD001 & & & & & & $\cdot$ & Phase $1 / \|$ recruiting \\
\hline Sorafenib* & & $\cdot$ & $\cdot$ & & . & & Phase III complete \\
\hline Sunitinib* & & $\cdot$ & $\cdot$ & & & & Phase II ongoing \\
\hline Thalidomide & . & & & & & & Phase III recruiting \\
\hline
\end{tabular}

*Sorafenib and sunitinib are multi-tyrosine kinase inhibitors having both anti-proliferative and anti-angiogenic effects 
patients achieved a PR, while median PFS and overall survival (OS) were 9.1 and 15.9 months, respectively [126].

All these seemingly promising results are mostly based on small, non-randomized phase II studies.

\subsection{Sunitinib}

Another potential promising multitargeting agent is sunitinib, which is an inhibitor of VEGFR, PDGFR- $\alpha$ and $\beta, \mathrm{c}-$ kit, Flt-3 and RET kinases [127].

European/Asian phase II study explored the safety and efficacy of sunitinib dosed at $50 \mathrm{mg}$ daily for 4 weeks in 37 patients with unresectable HCC. Since only one PR was confirmed, with prevalent SD recorded, the trial did not proceed to the second stage. Moreover, Sunitinib showed pronounced toxicities at a dose of $50 \mathrm{mg} /$ day in patients with unresectable $\mathrm{HCC}$. The response rate was low, and the study did not meet the primary endpoint based on RECIST criteria [128].

Different chemotherapy strategies to use in $\mathrm{HCC}$ treatment exploit the intrinsic oxidative stress of tumour cells. The first attempt to employ in vivo pro-oxidant agents was reported by Nathan e Chon in 1981 that used the glucose oxidase as $\mathrm{H} 2 \mathrm{O} 2$ precursor obtaining a significant decrease of tumour growth [129]. Various chemotherapy agents actually in use, including doxorubicin, vinblastine, vincristine and camptotecin, have a redox $\mathrm{H}_{2} \mathrm{O}_{2}$-mediated activity [130] on tumour cells without effects on health tissues [131].

The main systemic therapy to prolong survival in patients with advanced $\mathrm{HCC}$ and the new reference standard for systemic treatment for these patients is sorafenib [132].

\subsection{Sorafenib}

Sorafenib (Nexavar BAY 43-9006) is a multikinase inhibitor that has shown efficacy against a wide variety of tumours in preclinical models and clinical studies.

It has been shown to block tumour cell proliferation and angiogenesis by inhibiting serine/ threonine kinases [c-RAF, and mutant and wildtype B-RAF (v-raf murine sarcoma viral oncogene homolog $\mathrm{B} 1$ )] as well as the receptor tyrosine kinases VEGFR2, VEGFR3, PDGFR, FLT3, RET and C-KIT. On the other hand, it is known that the overexpression and/or mutation of Raf kinase is a common event in several tumours, including HCC. In fact, RAF kinases are key regulators of the MEKERK cascade and up-regulated signalling through the RAF/ MEK/ERK pathway has an important role in HCC [133].

The efficacy of sorafenib on HCC has been confirmed in both phase II and phase III trials [134-136]. In the large randomized phase III Sorafenib HCC Assessment Randomized Protocol (SHARP)-SHARP study, 602 patients with biopsy-proven advanced HCC who had not received any prior systemic treatment were evaluated and randomized to receive either sorafenib (400 mg twice daily, $\mathrm{n}=299$ ) or a placebo. The primary endpoints were OS and time to symptomatic progression, while the secondary endpoint was time to progression (TTP). The results demonstrated a significant improvement in both OS (median 10.7 vs 7.9 months) and TTP (median 5.5 vs 2.8 months) in the sorafenib group vs the placebo group. These results indeed represented a $44 \%$ increase in OS and 73\% prolongation in the TTP.

The SHARP protocol represents the first large-scale randomized trial that demonstrates the OS benefit of systemic treatment in patients with advanced HCC thus far, and therefore it has been approved by the US Food and Drug Administration for the treatment of advanced HCC patients. However, this study was conducted mainly in the western countries, where the main etiologies of $\mathrm{HCC}$ are $\mathrm{HCV}$ and alcohol. In contrast, the main bulk of HCC occurs in Asian countries, where chronic HBV infection accounts for the majority of HCC cases. Therefore, similar to the design of the SHARP study, an Oriental sorafenib study was performed to investigate the efficacy and tolerability of using single-agent sorafenib in treating advanced HCC patients in Asian population.

In this study, the median OS of patients on sorafenib was 6.2 months, which was significantly better than 4.1 months achieved in patients on placebo.

Although these two pivotal studies have demonstrated good activity and tolerability in treating advanced HCC patients with sorafenib, it is still far from an efficient control of this disease.

The combination of sorafenib with agents active in the control of the HCC-derived symptoms could be useful in the clinical strategy of $\mathrm{HCC}$ in order to increase treatment tolerability.

Combination of molecular therapies is expected to improve the outcome benefits obtained with sorafenib, but this is a highly complex matter due to the complexity of complementary pathways activated in HCC. Examples of this are given by the combination of sorafenib with anti-angiogenic agents and blockers of cell proliferation, such as EGFR, MET, and IGFR inhibitors. An alternative strategy is to combine therapies abrogating complementary intracellular signaling, such as RAS or mTOR inhibitors. Similarly, proapoptotic agents might synergize with cell proliferation inhibitors [59,137]

\subsection{Octreotide}

Differential somatostatin receptor subtypes (SSTR 1, 2, 3 and 5) are expressed in HCC [138]. Somatostatin analogues, such as octreotide, which display high binding affinity to SSTR2 and lower affinity to SSTR5 and SSTR3 (affinity rank order: SSTR2 > SSTR5 > SSTR3) are 
efficacious in the treatment of neuroendocrine tumors and exhibit only mild toxicity [139].

Octreotide LAR (long-acting release) is a formulation of octreotide encapsulated into microspheres of the biodegradable glucose star polymer [140]. This synthetic version of somatostatin differs from the latter for the prolonged half-life that allows to administer the drug every 28 days to obtain active plasma concentrations.

As somatostatin, octreotide reduces the release of growth factors and inhibits neo-angiogenesis. Octreotide was previously used in HCC patients with conflicting results [140,141]. However, approximately $40 \%$ of patients respond to octreotide with improved survival and an impressive quality of life [142]. We showed, in a previous study, that combination of octreotide and radiofrequency ablation produced about $80 \%$ of disease control and interesting mean OS (31.4 months) in a series of advanced HCC patients [143]. Investigations on octreotide in HCC are still ongoing also as National Cancer Institute sponsored trials [144,145].

Based on these premises, our group started a phase II multicenter study based on the combination between sorafenib and octreotide LAR (So.LAR protocol) in order to assess its safety and activity in advanced HCC patients [146]. Five PR (10\%), 33 SD (66\%) and 12 PD (24\%) were recorded. Overall disease control rate (CR $+\mathrm{PR}+\mathrm{SD}$ ) was $76 \%$. In conclusion, the combination between sorafenib and octreotide LAR was active and well tolerated in advanced HCC [139]. Moreover, we have investigated on the pharmaco-dynamic interference between the two agents and the level of Erk activation that serves as a surrogate of the inhibition induced by Sorafenib [147]. In details, we have evaluated the effects of So.LAR treatment on Erk activity in PBMC of patients affected by $\mathrm{HCC}$ with cytofluorimetric technique. We found a gradual reduction of Erk1/2 activity in 15 patients responsive to the treatment reaching an about 50\% maximal decrease after 21 days (T21) from the beginning of therapy. On the other hand, in 17 patients resistant to treatment the activity of Erk1/2 was about $80 \%$ increased at T21. An opposite trend of intracellular $\mathrm{O}^{2-}$ levels was observed in resistant patients. These effects were correlated to the modulation of SOD activity (physiological scavenger of $\mathrm{O}^{2-}$ ) and of serum NO levels. In fact, in 20 responder patients, sorafenib alone induced an increase of about $40 \%$ of NO levels and of about 2-fold of SOD activity and this latter effect was significantly potentiated after the addition of octreotide LAR. In conclusion, the determination of both pErk expression in PBMC and the oxidative stress status have high value in the prediction of response to sorafenib +octreotide therapy in HCC patients.

The increased generation of acute intracellular oxidative stress, which results from the generation of reactive oxygen species (ROS) by environmental factors or cellular mitochondrial alterations, has recently been associated with the progression of chronic liver diseases and hepatocarcinogenesis. On the other hand, a distinctive pathological hallmark of $\mathrm{HCC}$ is a dramatic down-regulation of oxidoreductase enzymes that constitute the most important free radical scavenger systems represented by catalase, SOD and glutathione peroxidase [87,148-150].

\section{Biomarkers of oxidative stress}

One strong mechanistic link between chronic inflammation and cancer is through the increased production of free radicals at the site of inflammation and the resulting molecular changes, which include lipid peroxidation and oxidative DNA damage [151]. Indeed, markers of DNA damage, such as 8-hydroxydeoxyguanosine (8OHdG), and lipid peroxidation, such as 4-hydroxynonenal (HNE) and malondialdehyde (MDA), are commonly elevated in liver of patients with chronic HCV infection and correlate well with the degree of viral infection and inflammation, known risk factors for HCC [152].

In addition to the classical genetic mechanisms of deletion or inactivating point mutations, epigenetic alterations, such as hyperacetylation of the chromatinassociated histones are believed to be involved in the development and progression of HCC. Histone deacetylases (HDACs) are important regulators of many oxidative stress pathways including those involved with both sensing and coordinating the cellular response to oxidative stress. In particular aberrant regulation of these pathways by HDACs may play critical roles in cancer progression. Infact, HA-But, an HDAC inhibitor in which butyric acid residues are esterified to a hyaluronic acid backbone and characterized by a high affinity for the membrane receptor CD44, valproic acid and ITF2357, exhibiting inherent therapeutic activity against HCC may represent a promising approach for HCC treatment $[153,154]$.

It is well known that inflammation is one of the biological responses driven by oxidative stress. Modulation of oxidative damage as well as inflammation protect against hepatocarcinogenesis. It has been shown that resveratrol, a compound present in grapes and red wine, has potent antioxidant [155] and anti-inflammatory [156] properties, which might play an important role in protecting the liver against carcinogen-induced neoplasia. Recently, it was reported that resveratrol significantly prevents diethylnitrosamine (DENA)-induced liver tumorigenesis in rats [157].

\section{Conclusions}

HCC is a disease that presents two relevant concerns: i) the presence of a cirrhotic background that severely 
affects both the quality of life and the survival of the patients and ii) the pleiotropic pathogenesis that has as common background: the chronic inflammation and the oxidative stress. The pharmacological weapons against HCC are still limited and efficacy has been established only for the multiple kinase inhibitor sorafenib. We have recently demonstrated that sorafenib plus octreotide is a safe and effective option in advanced HCC patients with compromised metabolic scores and/or low performance status. A still limited covered area of research in HCC is represented by the oxidative stress that underlies primary liver tumour development and that occurs through the generation of ROS and/or RNS and that is regulated by several scavenger mechanisms. On this view, we have found that the determination of oxidative stress status has high value in the prediction of response to sorafenib plus octreotide therapy in HCC patients. These data could have a profound impact in the determination of the sensitivity of the patients to this pharmacological strategy and could have a role in the selection of the patients to be subjected to this treatment. This could reduce both the relevant side effects correlated to the therapy and the relevant costs derived from the use of expensive drugs such as the new target based agents such as sorafenib. The factors involved in the oxidative stress could have a role not only in the prediction of response to pharmacological treatments but could be themselves targets of drugs as in the case of the stress-dependent kinases p38 kinase and Jun kinase or in the case of the use of anti-oxidant agents such as resveratrol or silibin. The investigations on oxidative stress and on its connection with signal transduction pathways correlated to survival and/or proliferation could disclose new scenarios of interventions based on the rational use of anti-oxidant agents in combination with target based drugs.

\section{Author details \\ 'Department of Biochemistry and Biophysics, Second University of Naples, Naples, Italy. ${ }^{2}$ Department of Anaesthesiology and Special Surgery, Second University of Naples, Naples, Italy. ${ }^{3}$ Departement of Experimental Medicine, Sezione di Medicina del lavoro, Igiene e Tossicologia Industriale, Second University of Naples, Naples, Italy. ${ }^{4}$ Interventional US Unit, Department of Medicine, S. Giovanni di Dio Hospital, 80059 Torre del Greco (Naples), Italy. ${ }^{5}$ Animal Facility Unit, National Institute of Tumours "Fondazione G. Pascale" of Naples, Naples, Italy. ${ }^{6}$ Department of Morphopathology, II University Naples, Napoli, Italy.}

\section{Authors' contributions}

$M M, M C, M L, A L, A A$ and PS have critically revised the manuscript and have made substantial contributions to conception MA, IMS, LT, AG, MA, PS and RS have been involved in drafting the manuscript. MC, MM and PS have given final approval of the version to be published. All authors have read and approved the final manuscript.

\section{Competing interests}

The authors declare that they have no competing interests.
Received: 22 April 2011 Accepted: 10 October 2011

Published: 10 October 2011

\section{References}

1. McGlynn KA, Tsao L, Hsing AW, Devesa SS, Fraumeni JF Jr: International trends and patterns of primary liver cancer. Int J Cancer 2001, 94:290-6.

2. Bosch FX, Ribes J, Díaz M, Cléries R: Primary Liver Cancer: Worldwide Incidence and Trends. Gastroenterology 2004, 127:S5-S16.

3. Larson AM: The Epidemiology of Hepatocellular Carcinoma in HCV. Curr Hepat Reps 2005, 4:145-152.

4. Levi F, Lucchini F, Negri E, La Vecchia C: Continuing declines in cancer mortality in the European Union. Ann Oncol 2007, 18:593-595.

5. Montalto G, Cervello M, Giannitrapani L, Dantona F, Terranova A, Castagnetta LA: Epidemiology, risk factors, and natural history of hepatocellular carcinoma. Ann N Y Acad Sci 2002, 963:13-20.

6. La Vecchia C, Negri E, Pilucchi C: The rise and fall in primary liver cancer mortality in Italy. Dig Liver Dis 2002, 34:169-171.

7. Okuda K: Hepatocellular carcinoma: recent progress. Hepatology 1992, 15:948-63.

8. Liu JH, Chen PW, Asch SM, Busuttil RW, Ko CY: Surgery for hepatocellular carcinoma: does it improve survival? Ann Surg Oncol 2004, 11:298-303.

9. Bosch FX, Ribes J, Borràs J: Epidemology of primary liver cancer. Semin Liver Dis 1999, 193:271-85.

10. Yang JC, Teng CF, Wu HC, Tsai HW, Chuang HC, Tsai TF, Hsu YH, Huang W, Wu LW, Su IJ: Enhanced expression of vascular endothelial growth factor-A in ground glass hepatocytes and its implication in hepatitis B virus hepatocarcinogenesis. Hepatology 2009, 496:1962-71.

11. lavarone M, Lampertico P, lannuzzi F, Manenti E, Donato MF, Arosio E, Bertolini F, Primignani M, Sangiovanni A, Colombo M: Increased expression of vascular endothelial growth factor in small hepatocellular carcinoma. J Viral Hepat 2007, 142:133-9.

12. De Giorgi V, Monaco A, Worchech A, Tornesello M, Izzo F, Buonaguro L, Marincola FM, Wang E, Buonaguro FM: Gene profiling, biomarkers and pathways characterizing HCV-related hepatocellular carcinoma. J Trans/ Med 2009, 12(7):85.

13. Besaratinia A, Kim SI, Hainaut P, Pfeifer GP: In vitro recapitulating of TP53 mutagenesis in hepatocellular carcinoma associated with dietary aflatoxin B1 exposure. Gastroenterology 2009, 1373:1127-37.

14. Yu MC, Yuan JM: Environmental factors and risk for hepatocellular carcinoma. Gastroenterology 2004, 127:572-8

15. Franceschi S, Montella M, Polesel J, La Vecchia C, Crispo A, Dal Maso L, Casarin P, Izzo F, Tommasi LG, Chemin I, Trépo C, Crovatto M, Salamini R: Hepatitis viruses, alcohol, and tobacco in the etiology of hepatocellular carcinoma in Italy. Cancer Epidemiol Biomarkers Prev 2006, 154:683-9.

16. Adkins RH: Clinical significance of concomitant hepatitis $\mathrm{C}$ infection in patients with alcoholic liver disease. Hepatology 1994, 19:554-557.

17. Ming L, Thorgeirsson SS, Gail MH, Lu P, Harris CC, Wang N, Shao Y, Wu Z, Liu G, Wang X, Sun Z: Dominant role of hepatitis B virus and cofactor role of aflatoxin in hepatocarcinogenesis in Qidong, China. Hepatology 2002, 36:1214-1220.

18. Hassan MM, Hwang LY, Hatten CJ, Swaim M, Li D, Abbruzzese JL, Beasley P, Patt YZ: Risk factors for hepatocellular carcinoma: synergism of alcohol with viral hepatitis and diabetes mellitus. Hepatology 2002, 36:1206-1213.

19. Ohata K, Hamasaki K, Toriyama K, Matsumoto K, Saeki A, Yanagi K, Abiru S, Nakagawa Y, Shigeno M, Miyazoe S, Ichikawa T, Ishikawa H, Nakao K, Educhi K: Hepatic steatosis is a risk factor for hepatocellular carcinoma in patients with chronic hepatitis C virus infection. Cancer 2003, 97:3036-3043.

20. El-Serag HB, Richardson PA, Everhart JE: The role of diabetes in hepatocellular carcinoma: a case-control study among United States Veterans. Am J Gastroenterol 2001, 96:2462-2467.

21. Davila JA, Morgan RO, Shaib Y, McGlynn KA, El-Serag HB: Diabetes increases the risk of hepatocellular carcinoma in the United States: a population based case control study. Gut 2005, 54:533-539.

22. Chokshi MM, Marrero JA: Hepatocellular carcinoma. Curr Opin Gastroenterol 2001, 17:276-280.

23. Hanahan D, Weinberg RA: The hallmarks of cancer. Cell 2000, 100:57-70.

24. Theise ND, Park YN, Kojiro M: Dysplastic nodules and hepatocarcinogenesis. Clin Liver Dis 2002, 6:497-512.

25. Borzio M, Fargion S, Borzio F, Fracanzani AL, Croce AM, Stroffolini T, Oldani S, Cotichini R, Roncalli M: Impact of large regenerative, low grade 
and high grade dysplastic nodules in hepatocellular carcinoma development. J Hepatol 2003, 39:208-214.

26. Branda M, Wands JR: Signal transduction cascades and hepatitis B and C related hepatocellular carcinoma. Hepatology 2006, 43:891-902.

27. Roskams TA, Libbrecht L, Desmet VJ: Progenitor cells in diseased human liver. Semin Liver Dis 2003, 23:385-396.

28. Kiyosawa K, Sodeyama T, Tanaka E, Gibo Y, Yoshizawa K, Nakano Y, Furuta S, Akahane Y, Nishioka K, Purcell RH, Alter HJ: Interrelationship of bloodtransfusion, non-A, non-B hepatitis and hepatocellular carcinoma: analysis bydetection of antibody to hepatitis C virus. Hepatology 1990, 12:671-675.

29. McMahon BJ: Epidemiology and natural history of hepatitis B. Semin Liver Dis 2005, 25:S3-S8

30. Seeger C, Mason WS: Hepatitis B virus biology. Microbiol Mol Biol Rev 2000, 64(1):51-68

31. Thorgeirsson SS, Grisham JW: Molecular pathogenesis of human hepatocellular carcinoma. Nat Genet 2002, 31:339-346.

32. Feitelson MA: Hepatitis B virus in hepatocarcinogenesis. J Cell Physiol 1999, 181(2):188-202

33. Yuen MF, Wu PC, Lai VC, Lau JY, Lai CL: Expression of c-Myc, c-Fos, and cjun in hepatocellular carcinoma. Cancer 2001, 911:106-12.

34. Chirillo P, Pagano S, Natoli G, Puri PL, Burgio VL, Balsano C, Levrero M: The hepatitis $B$ virus $X$ gene induces $p 53$-mediated programmed cell death Proc Natl Acad Sci USA 1997, 94:8162-8167.

35. Sirma H, Giannini C, Poussin K, Paterlini P, Kremsdorf D, Brechot C: Hepatitis $B$ virus $X$ mutants, present in hepatocellular carcinoma tissue abrogate both the antiproliferative and transactivation effects of $\mathrm{HBx}$. Oncogene 1999, 18:4848-4859.

36. Hu Z, Zhang Z, Doo E, Coux O, Goldberg AL, Liang TJ: Hepatitis B virus $x$ protein is both a substrate and a potential inhibitor of the proteasome complex. J Virol 1999, 73:7231-7240.

37. $X u Z$, Jensen $G$, Yen TS: Activation of hepatitis B virus $S$ promoter by the viral large surface protein via induction of stress in the endoplasmic reticulum. J Virol 1997, 71:7387-7392.

38. Baozong Li, Bo Gao, Linbai Ye, Xue Han, Wei Wang, Lingbao Kong, Xiaonan Fang, Yingchun Zeng, Hong Zheng, Shanshan Li, Zhenghui Wu, Li Ye: Hepatitis B virus X protein (HBX) activates ATF6 and IRE1-XBP1 pathways of unfolded protein response. Virus Research 2007, 124:44-49.

39. Tellinghuisen, Rice : Interaction between hepatitis $C$ virus proteins and host cell factors. Curr Opin Microbiol 2002, 5(4):419-27.

40. Westaway EG, Mackenzie JM, Kenney MT, Jones MK, Khromykh AA: Ultrastructure of Kunjin virusinfected cells: colocalization of NS1 and NS3 with doublestranded RNA, and of NS2B with NS3, in virus-induced membrane structures. J Virol 1997, 71:6650-6661.

41. Weiland F, Eiland E, Nger G, Sallmuller A, Thiel H: Localization of pestivrial envelope proteins Erns and E2 at the cell surface and on isolated particles. J Gen Virol 1999, 80:1157-1165.

42. Bartenschlager R, Lohmann V: Replication of hepatitis C virus. J Gen Virol 2000, 81:1631-1648.

43. Parkin DM, Bray F, Ferlay J, Pisani P: Estimatine the world cancer burden: Globocan 2000. Int I Cancer 2001, 94:153-156.

44. Giambartolomei S, Covone F, Levrero M, Balsano C: Sustained activation of the Raf/MEK/Erk pathway in response to EGF in stable cell lines expressing the Hepatitis C Virus HCV core protein. Oncogene 2001, 20:2606-2610.

45. Ray RB, Steele R, Meyer K, Ray R: Transcriptional repression of $p 53$ promoter by hepatitis C virus core protein. J Biol Chem 1997, 272:10983-10986.

46. Lu W, Lo SY, Chen M, Wu K, Fung YK, Ou JH: Activation of p53 tumor suppressor by hepatitis C virus core protein. Virology 1999, 264:134-141.

47. Alisi A, Giambartolomei S, Cupelli F, Merlo P, Fontemaggi G, Spaziani A: Physical and functional interaction between HCV core protein and the different p73 isoforms. Oncogene 2003, 22:2573-2580.

48. Cho J, Baek W, Yang S, Chang J, Sung YC, Suh M: HCV core protein modulates $\mathrm{Rb}$ pathway through $\mathrm{pRb}$ down-regulation and E2F-1 upregulation. Biochim Biophys Acta 2001, 1538:59-66.

49. Wang F, Yoshida I, Takamatsu M, Ishido S, Fujita T, Oka K: Complex formation between hepatitis $C$ virus core protein and p21Waf1/Cip1/ Sdi1. Biochem Biophys Res Commun 2000, 273:479-484.
50. Varaklioti A, Vassilaki N, Georgopoulou U, Mavromara P: Alternate translation occurs within the core coding region of the hepatitis $C$ viral genome. J Biol Chem 2002, 277:17713-17721.

51. Yamanaka T, Uchida M, Doi T: Innate form of HCV core protein plays an important role in the localization and the function of HCV core protein. Biochem Biophys Res Commun 2002, 294:521-527.

52. Capitanio N, Moradpour D, Piccoli C: Hepatitis C virus proteins promote mitochondrial bioenergetic dysfunction and nitro-oxidative stress: insights into pathogenesis. Drug Discovery Today: Disease Mechanisms 2009, 6:e3-e10.

53. Jordan R, Wang L, Graczyk TM, Block TM, Romano PR: Replication of a cytopathic strain of bovine viral diarrhea virus activates PERK and induces endoplasmic reticulum stress-mediated apoptosis of MDBK cells. J Virol 2002, 76:9588-9599.

54. Tardif KD, Mori K, Siddiqui A: Hepatitis C virus subgenomic replicons induce endoplasmic reticulum stress activating an intracellular signaling pathway. J Virol 2002, 76:7453-7459.

55. Waris G, Tardif KD, Siddiqui A: Endoplasmic reticulum (ER) stress: hepatitis $\mathrm{C}$ virus induces an ER-nucleus signal transduction pathway and activates NF-kappaB and STAT-3. Biochem Pharmacol 2002, 64:1425-1430.

56. Ferber MJ, Montoya DP, Yu C, Aderca I, McGee A, Thorland EC, Nagorney DM, Gostout BS, Burgart L, Boix L, Bruix J, Mcmahon BJ, Cheung TH, Chung T, Wong YM, Smith DI, Roberts LR: Integrations of the hepatitis $B$ virus $\mathrm{HBV}$ and human papillomavirus HPV into the human telomerase reverse transcriptase hTERT gene in liver and cervical cancers. Oncogene 2003, 22:3813-3820.

57. Farazi PA, De Pinho RA: Hepatocellular carcinoma pathogenesis: from genes to environment. Nat Rev Cancer 2006, 6:674-687.

58. Taniguchi H, Kato N, Otsuka M, Goto T, Yoshida H, Stiratori Y, Omata M: Hepatitis $\mathrm{C}$ virus core protein upregulates transforming growth factorbeta 1 transcription. J Med Virol 2004, 72:52-59.

59. Lee JS, Thorgeirsson SS: Comparative and integrative functional genomics of HCC. Oncogene 2006, 25:3801-3809.

60. Llovet JM, Bruix J: Molecular targeted therapies in hepatocellular carcinoma. Hepatology 2008, 484:1312-1327.

61. Edamoto Y, Hara A, Biernat W, Terracciano L, Cathomas G, Riehle HM Matsuda M, Fujii H, Scoazec JY, Ohgaki H: Alterations of RB1, p53 and Wnt pathways in hepatocellular carcinomas associated with hepatitis $C$, hepatitis B and alcoholic liver cirrhosis. Int I Cancer 2003, 106:334-341.

62. Liu YC, Chen CJ, Wu HS, Chan DC, Yu JC, Yang AH, Cheng YL, Lee SC, Harn HJ: Telomerase and c-myc expression in hepatocellular carcinomas. Eur J Surg Oncol 2004, 30:384-390

63. Masaki T, Shiratori Y, Rengifo W, Igarashi K, Yamagata M, Kurokohchi K Uchida N, Miyauchi Y, Yoshiji H, Watanabe S, Omata M, Kuriyama S: Cyclins and cyclin-dependent kinases: comparative study of hepatocellular carcinoma versus cirrhosis. Hepatology 2003, 37:534-543.

64. Calvisi DF, Conner EA, Ladu S, Lemmer ER, Factor VM, Thorgeirsson SS: Activation of the canonical Wnt/beta-catenin pathway confers growth advantages in C-Myc/E2F1 transgenic mouse model of liver cancer. $J$ Hepatol 2005, 42:842-849.

65. Endo K, Ueda T, Ueyama J, Ohta T, Terada TTerada: Immunoreactive Ecadherin, alpha-catenin, beta-catenin, and gamma-catenin proteins in hepatocellular carcinoma: relationships with tumor grade, clinicopathologic parameters, and patients' survival. Hum Pathol 2000, 31:558-565.

66. Inagawa S, Itabashi M, Adachi S, Kawamoto T, Hori M, Shimazaki J, Yoshimi F, Fukao K: Expression and prognostic roles of beta-catenin in hepatocellular carcinoma: correlation with tumor progression and postoperative survival. Clin Cancer Res 2002, 8:450-456.

67. Merle P, de la Monte S, Kim M, Herrmann M, Tanaka S, Bussche A, Von Dem Kew MC, Trepo C, Wands JR: Functional consequences of frizzled-7 receptor overexpression in human hepatocellular carcinoma. Gastroenterology 2004, 127:1110-1122.

68. Merle P, Kim M, Herrmann M, Gupte A, Lefrancois L, Califano S, Trepo C, Tanaka S, Vitvitski L, de la Monte S, Wands JR: Oncogenic role of the frizzled-7/beta-catenin pathway in hepatocellular carcinoma. J Hepatol 2005, 43:854-862

69. Kim M, Lee HC, Tsedensodnom O, Hartley R, Lim YS, Yu E, Merle P, Wands JR: functional interaction between Wnt3 and Frizzled-7 leads to activation of the Wnt/beta-catenin signaling pathway in hepatocellular carcinoma cells. J Hepatol 2008, 485:780-91. 
70. Lee TH, Tai DI, Cheng CJ, Sun CS, Lin CY, Sheu MJ, Lee WP, Peng CY, Wang AH, Tsai SL: Enhanced nuclear factor-kappa B-associated Wnt-1 expression in hepatitis B- and C-related hepatocarcinogenesis: identification by functional proteomics. J Biomed Sci 2006, 131:27-39.

71. Marshall C: How do small GTPase signal transduction pathways regulate cell cycle entry? Curr Opin Cell Biol 1999, 11:732-736.

72. Hoscino R, Chatani Y, Yamori T, Tsuruo T, Oka H, Yoshida O, Shimada Y, Arii S, Wada H, Fujimoto J, Kohno M: Constitutive activation of the 41/43kDa mitogen-activated protein kinase signaling pathway in human tumors. Oncogene 1999, 18:813-22.

73. Calvisi DF, Pinna F, Ladu S, Pellegrino R, Sanna V, Sini M, Daino L, Simile MM, De Miglio MR, Frau M, Tomasi ML, Seddaiu MA, Muroni MR, Feo F, Pascale RM: Ras-driven proliferation and apoptosis signaling during rat liver carcinogenesis is under genetic control. Int J Cancer 2008, 123:2057-2064

74. Feo F, De Miglio MR, Simile MM, Muroni MR, Calvisi DF, Frau M, Pascale RM: Hepatocellular carcinoma as a complex polygenic disease. Interpretive analysis of recent developments on genetic predisposition. Biochim Biophys Acta 2006, 1765::126-147.

75. Pascale RM, Simile MM, De Miglio MR, Nufris A, Seddaiu MA, Muroni MR, Danni O, Rao KN, Feo F: Inhibition of 3-hydroxy-3-methylglutaryl-CoA reductase activity and gene expression by dehydrocpiandrosterone in preneoplastic liver nodules. Carcinogenesis 1995, 16:1537-1542.

76. Newell P, Toffanin S, Villanueva A, Chiang DY, Minguez B, Cabellos L, Savic R, Hoshida Y, Lim KH, Melgar-Lesmes P, Yea S, Peix J, Deniz K, Fiel MI, Thung S, Alsinet C, Tovar V, Mazzaferro V, Bruix J, Roayaie S, Schwartz M Friedman SL, Llovet JM: Ras pathway activation in hepatocellular carcinoma and anti-tumoral effect of combined sorafenib and rapamycin in vivo. J Hepatol 2009, 51:725-733.

77. Downward J: Targeting RAS signalling pathways in cancer therapy. Nat Rev Cancer 2003, 3:11-22.

78. Hwang YH, Choi JY, Kim S, Chung ES, Kim T, Koh SS, Lee B, Bae SH, Kim J, Park YM: Over-expression of c-raf-1 proto-oncogene in liver cirrhosis and hepatocellular carcinoma. Hepatol Res 2004, 29:113-121.

79. Semela D, Dufour JF: Angiogenesis and hepatocellular carcinoma. J Hepatol 2004, 41:864-880

80. Lee JS, Grisham JW, Thorgeirsson SS: Comparative functional genomics for identifying models of human cancer. Carcinogenesis 2005, 266:1013-1020.

81. Okey $A B$ : An aryl hydrocarbon receptor odyssey to the shores of toxicology: the Deichmann Lecture, International Congress of Toxicology-XI. Toxicol Sci 2007, 98:5-38.

82. Jesenberger $V$, Jentsch $S$ : Deadly encounter: ubiquitin meets apoptosis. Nat Rev Mol Cell Biol 2002, 3:112-121.

83. Kim JW, Wang XW: Gene expression profiling of preneoplastic liver disease and liver cancer: a new era for improved early detection and treatment of these deadly diseases? Carcinogenesis 2003, 24:363-369.

84. Finkel T, Holbrook NJ: Oxidants, oxidative stress and the biology of ageing. Nature 2000, 408:239-247

85. Storz P: Reactive oxygen species in tumor progression. Front Biosci 2005 10:1881-96.

86. Fruehauf JP, Meyskens FL Jr: Reactive Oxygen Species: A Breath of Life or Death? Clin Cancer Res 2007, 133:789-94.

87. Clemente C, Elba S, Buongiorno G, Guerra V, D'Attoma B, Orlando A, Russo F: Manganese superoxide dismutase activity and incidence of hepatocellular carcinoma in patients with Child-Pugh class $A$ liver cirrhosis: a 7-year follow-up study. Liver Int 2007, 276:791-7.

88. Ridnour LA, Thomas DD, Switzer C, Flores-Santana W, Isenberg JS, Ambs S, Roberts DD, Wink DA: Molecular mechanisms for discrete nitric oxide levels in cancer. Nitric Oxide 2008, 19.73-76.

89. Prueitt RL, Boersma BJ, Howe TM, Goodman JE, Thomas DD, Ying L, Pfiester CM, Yfantis HG, Cottrell JR, Lee DH, Remaley AT, Hofseth LJ, Wink DA, Ambs S: Inflammation and IGF-I activate the Akt pathway in breast cancer. Int J Cancer 2007, 120:796-805.

90. Thomas DD, Espey MG, Ridnour LA, Hofseth LJ, Mancardi D, Harris CC, Wink DA: Hypoxic inducible factor 1alpha, extracellular signal-regulated kinase, and p53 are regulated by distinct threshold concentrations of nitric oxide. Proc Natl Acad Sci USA 2004, 101:8894-8899.

91. Pervin S, Singh R, Freije WA, Chaudhuri G: MKP-1-induced dephosphorylation of extracellular signal-regulated kinase is essential for triggering nitric oxide-induced apoptosis in human breast cancer cell lines: implications in breast cancer. Cancer Res 2003, 63:8853-8860.
92. Thomas DD, Ridnour LA, Espey MG, Donzelli S, Ambs S, Hussain SP, Harris CC, DeGraff W, Roberts DD, Mitchell JB, Wink DA: Superoxide fluxes limit nitric oxide-induced signalling. J Biol Chem 2006, 281:25984-25993.

93. Hausladen A, Stamler JS: Nitrosative stress. Methods Enzymol 1999, 300:389-95.

94. Bogdan C, Röllinghoff M, Diefenbach AM: The role of nitric oxide in innate immunity. Immunol Rev 2000, 173:17-26.

95. Kim YM, Son K, Hong SJ, Green A, Chen JJ, Tzeng E, Hierholzer C, Billiar TR: Inhibition of protein synthesis by nitric oxide correlates with cytostatic activity: nitric oxide induces phosphorylation of initiation factor elF-2 alpha. Mol Med 1998, 4:179-190.

96. Bundy RE, Marczin N, Chester AH, Yacoub M: A redox-based mechanism for nitric oxide-induced inhibition of DNA synthesis in human vascular smooth muscle cells. Br. J Pharmacol 2000, 129:1513-1521.

97. Fujii J, Taniguchi N: Down regulation of superoxide dismutases and glutathione peroxidase by reactive oxygen and nitrogen species. Free Radic Res 1999, 31:301-308

98. Berendji D, Kolb-Bachofen V, Meyer KL, Kröncke KD: Influence of nitric oxide on the intracellular reduced glutathione pool: different cellular capacities and strategies to encounter nitric oxide-mediated stress. Free Radic Biol Med 1999, 27:773-780.

99. Murphy MP: Nitric oxide and cell death. Biochim Biophys Acta 1999, 1411:401-414.

100. Halliwell B: Reactive oxygen species in living systems: source, biochemistry, and role in human disease. Am J Med 1991, 91:14S-22S.

101. Wink DA, Miranda KM, Espey MG, Pluta RM, Hewett SJ, Colton C, Vitek M, Feelisch M, Grisham MB: Mechanisms of the antioxidant effects of nitric oxide. Antioxid Redox Signal 2001, 3:203-13.

102. Kim YM, Bergonia H, Lancaster JR Jr: Nitrogen oxide-induced autoprotection in isolated rat hepatocytes. FEBS Lett 1995, 374:228-32.

103. Chiu JJ, Wung BS, Hsieh HJ, Lo LW, Wang DL: Nitric oxide regulates shear stress-induced early growth response-1. Expression via the extracellular signal-regulated kinase pathway in endothelial cells. Circ Res 1999, 85:238-246.

104. Wulf D: Free Radicals in the Physiological Control of Cell Function. Physiol Rev 2002, 82:47-95.

105. Ma Y, Hendershot LM: The unfolding tale of the unfolded protein response. Cell 2001, 107(7):827-30.

106. Kaufman RJ: Stress signaling from the lumen of the endoplasmic retiuclum: coordination of gene transcriptional and translational controls. Genes Dev 1999, 13:1211-1233.

107. Wang X, McCullough KD, Franke TF, Holbrook NJ: Epidermal growth factor receptor-dependent Akt activation by oxidative stress enhances cell survival. J Biol Chem 2000, 275:14624-14631

108. Block TM, Mehta AS, Fimmel CJ, Jordan R: Molecular viral oncology of hepatocellular carcinoma. Oncogene 2003, 22:5093-5107.

109. Sumida $Y$, Nakashima T, Yoh T, Nakjima $Y$, Ishikawa $H$, Mitsuyoshi $H$, Sakamoto Y, Okanoue T, Kashima K, Nakamura H, Yodoi J: Serum thioredoxin levels as an indicator of oxidative stress in patients with hepatitis C virus infection. J Hepatology 2000, 33:616-622.

110. Shimoda R, Nagashima M, Sakamoto M, Yamaguchi N, Hirohashi S, Yokota J, Kasai H: Increased formation of oxidative DNA damage, 8hydroxydeoxyguanosine, in human livers with chronic hepatitis. Cancer Res 1994, 54:3171-3172.

111. Moriya K, Nakagawa K, Santa T, Shintani Y, Fujie H, Miyoshi H, Tsutsumi T, Miyazawa T, Ishibashi K, Horie T, Imai K, Todoroki T, Kimura S, Koike K: Oxidative stress in the absence of inflammation in a mouse model for hepatitis C virus-associated hepatocarcinogenesis. Cancer Res 2001, 61:4365-4370.

112. Altimari A, Fiorentino M, Gabusi E, Gruppioni E, Corti B, D'Errico A Grigioni WF: Investigation of ErbB1 and ErbB2 expression for therapeutic targeting in primari liver tumours. Dig Liver Dis 2003, 35:332-338.

113. Forner A, Hessheimer AJ, Isabel Real M, Bruix J: Treatment of hepatocellular carcinoma. Crit Rev Oncol Hematol 2006, 602:89-98.

114. Fan ST, Lo CM, Liu CL, Lam CM, Yuen WK, Yeung C, Wong J: Hepatectomy for hepatocellular carcinoma: toward zero hospital deaths. Ann Surg 1999, 229:322-30.

115. Ota K, Teraoka S, Kawai T: Donor difficulties in Japan and Asian countries. Transplant Proc 1995, 27:83-6

116. Palmer DH, Hussain SA, Johnson PJ: Systemic therapies for hepatocellular carcinoma. Expert Opin Invest Drugs 2004, 13:1555-68. 
117. Woodburn JR: The epidermal growth factor receptor and its inhibition in cancer therapy. Pharmacol Ther 1999, 82:241-250.

118. Gibbs JB: Anticancer drug targets: Growth factors and growth factor signaling. J Clin Invest 2000, 105:9-13.

119. Kaneko Y, Shibuya M, Nakayama T, Hayashida N, Toda G, Endo Y, Oka H, Oda T: Hypomethylation of c-myc and epidermal growth factor receptor genes in human hepatocellular carcinoma and fetal liver. Jpn J Cancer Res 1985, 76:1136-1140.

120. Xu YH, Jiang WL, Peng SF: EGFR/HER1 expression and EGF stimulation of proliferation in human liver carcinoma cells. Shi Yan Sheng Wu Xue Bao 1989, 22:445-453.

121. Philip AP, Mahoney MR, Allmer C, Thomas J, Pitot HC, Kim G, Donehower RC, Fitch T, Picus J, Erlichman C: Study of Erlotinib OSI-774 in Patients With Advanced Hepatocellular Cancer. J Clin Oncol 2005, 23:6657-6663.

122. Thomas MB, Chadha R, Glover K, Wang X, Morris J, Brown T, Rashid A, Dancey J, Abbruzzese JL: Phase 2 study of erlotinib in patients with unresectable hepatocellular carcinoma. Cancer 2007, 1105:1059-67.

123. Zhu AX, Stuart K, Blaszkowsky LS, Muzikansky A, Reitberg DP, Clark JW, Enzinger PC, Bhargava P, Meyerhardt JA, Horgan K, Fuchs CS, Ryan DP: Phase 2 study of cetuximab in patients with advanced hepatocellular carcinoma. Cancer 2007, 1103:581-9.

124. Asnacios A, Fartoux L, Romano O, Tesmoingt C, Louafi SS, Mansoubakht T, Artru P, Poynard T, Rosmorduc O, Hebbar M, Taieb J: Gemcitabine plus oxaliplatin GEMOX combined with cetuximab in patients with progressive advanced stage hepatocellular carcinoma: results of a multicenter phase 2 study. Cancer 2008, 11212:2733-2739.

125. Siegel AB, Cohen El, Ocean A, Lehrer D, Goldenberg A, Knox JJ, Chen H, Clark-Garvey S, Weinberg A, Mandeli J, Christos P, Mazumdar M, Popa E, Brown RS Jr, Rafii S, Schwartz JD: Phase II trial evaluating the clinical and biologic effects of bevacizumab in unresectable hepatocellular carcinoma. J Clin Oncol 2008, 26:2992-8.

126. Thomas MB, Morris JS, Chadha R, Iwasaki M, Kaur H, Lin E, Kaseb A, Glover K, Davila M, Abbruzzese J: Phase II trial of the combination of bevacizumab and erlotinib in patients who have advanced hepatocellular carcinoma. J Clin Oncol 2009, 276:843-50.

127. Mendel DB, Laird AD, Xin X, Louie SG, Christensen JG, Li G, Schreck RE, Abrams TJ, Ngai TJ, Lee LB, Murray LJ, Carver J, Chan E, Moss KG, Haznedar JO, Sukbuntherng J, Blake RA, Sun L, Tang C, Miller T, Shirazian S, McMahon G, Cherrington JM: In vivo antitumor activity of SU11248, a novel tyrosine kinase inhibitor targeting vascular endothelial growth factor and platelet-derived growth factor receptors: determination of a pharmacokinetic/pharmacodynamic relationship. Clin Cancer Res 2003, 9:327-37.

128. Faivre S, Raymond E, Boucher E, Douillard J, Lim HY, Kim JS, Zappa M, Lanzalone S, Lin X, Deprimo S, Harmon C, Ruiz-Garcia A, Lechuga MJ, Cheng AL: Safety and efficacy of sunitinib in patients with advanced hepatocellular carcinoma: an open-label, multicentre, phase II study. Lancet Oncol 2009, 108:794-800.

129. Nathan CF, Cohn ZA: Antitumor effects of hydrogen peroxide in vivo. $J$ Exp Med 1981, 1545:1539-53.

130. Simizu Takada M, Umezawa K, Imoto M: Requirement of caspase-3-like protease-mediated hydrogen peroxide production for apoptosis induced by various anticancer drugs. J Biol Chem 1998, 273:26900-26907.

131. Yoshikawa T, Kokura S, Tainaka K, Naito Y, Kondo M: A novel cancer therapy based on oxygen radicals. Cancer Res 1995, 55:1617-1620.

132. Chaparro M, González Moreno L, Trapero-Marugán M, Medina J, MorenoOtero R: Review article: pharmacological therapy for hepatocellular carcinoma with sorafenib and other oral agents. Aliment Pharmacol Ther 2008, 2811-12:1269-77

133. Liu L, Cao Y, Chen C, Zhang X, McNabola A, Wilkie D, Wilhelm S, Lynch M, Carter C: Sorafenib blocks the RAF/MEK/ERK pathway, inhibits tumor angiogenesis, and induces tumor cell apoptosis in hepatocellular carcinoma model PLC/PRF/5. Cancer Res 2006, 66:11851-11858.

134. Abou-Alfa GK: Hepatocellular carcinoma:molecular biology and therapy. Semin Oncol 2006, 66:11851-858.

135. Abou-Alfa GK, Schwartz L, Ricci S, Amadori D, Santoro A, Figer A, De Greve J, Douillard J.-Y, Lathia C, Schwartz B, Taylor I, Moscovici M, Saltz LB: Phase II study of sorafenib in patients with advanced hepatocellular carcinoma. J Clin Oncol 2006, 24:4293-300.
136. Yau T, Chan P, Epstein R, Poon RT: Management ofadvanced hepatocellular carcinoma in the era of targeted therapy. Liver Int 2009, 291:10-7.

137. Llovet JM, Di Bisceglie A, Bruix J, Kramer BS, Lencioni R, Zhu AX, Sherman M, Schwartz M, Lotze M, Talwalkar J, Gores GJ: Design and endpoints of clinical trials in HCC. J Natl Cancer Inst 2008, 100:698-711.

138. Lamberts SW, van der Lely AJ, de Herder WW, Hofland LJ: Octreotide. N Engl J Med 1996, 334:246-254.

139. Dimitroulopoulos D, Xinopoulos D, Tsamakidis K, Zisimopoulos A Andriotis E, Panagiotakos D, Fotopoulou A, Chrysohoou C, Bazinis A, Daskalopoulou D, Paraskevas E: Long acting octreotide in the treatment of advanced hepatocellular cancer and overexpression of somatostatin receptors: Randomized placebo-controlled trial. World I Gastroenterol 2007, 1323:3164-3170

140. Attia S, Holen KD, Thomas JP, Richie K, Dzelak T, Teeter K, Warren D, Bilger A, Fine J, Eickhoff J, Drinkwater N, Mulkerin D, Morgan-Meadows S: Biologic study of the effects of octreotide-LAR on growth hormone in unresectable and metastatic hepatocellular carcinoma. Clin Adv Hematol Oncol 2008, 61:44-54.

141. Samonakis DN, Notas G, Christodoulakis N, Kouroumalis EA: Mechanisms of action and resistance of somatostatin analogues for the treatment of hepatocellular carcinoma: a message not well taken. Dig Dis Sci 2008, 53:2359-65.

142. Montella L, Addeo R, Caraglia M, Faiola V, Guarrasi R, Vincenzi B, Palmeri A, Capasso E, Nocera V, Tarantino L, Ariete M, Martorelli A, Del Prete S: Vascular endothelial growth factor monitoring in advanced hepatocellular carcinoma patients treated with radiofrequency ablation plus octreotide: A single center experience. Oncol Rep 2008, 20:385-90.

143. Therasse P, Arbuck SG, Eisenhauer EA, Wanders J, Kaplan RS, Rubinstein L, Verweij J, Van Glabbeke M, van Oosterom AT, Christian MC, Gwyther SG: New Guidelines to Evaluate the Response to Treatment in Solid Tumors. J Natl Cancer Inst 2000, 92:205-16.

144. Del Prete S, Montella L, Caraglia M, Maiorino L, Cennamo G, Montesarchio V, Piai G, Febbraro A, Tarantino L, Capasso E, Palmieri G, Guarrasi R, Bianco M, Mamone R, Savastano C, Pisano A, Vincenzi B, Sabia A, D'Agostino A, Faiola V, Addeo R: Sorafenib plus octreotide is an effective and safe treatment in advanced hepatocellular carcinoma: multicenter phase II So.LAR. study. Cancer Chemother Pharmacol 2009, 645:863-6.

145. Addeo R, Caraglia M, Del Prete S: Highlights of regional meeting of Italian Southern Oncological Group (GOIM): focus on hepatocellular carcinoma: biological and clinical background, therapeutic guide-lines and perspectives. 7 November 2008 Naples, Italy. Expert Opin Investig Drugs 2009, 18(3):373-8.

146. Corrocher R, Casaril M, Bellisola G, Gabrielli GB, Nicoli N, Guidi GC, De Sandre G: Severe impairment of antioxidant system in human hepatoma. Cancer 1986, 58:1658-1662.

147. Caraglia M, Giuberti G, Marra M, Addeo R, Montella L, Murolo M, Sperlongano P, Vincenzi B, Naviglio S, Del Prete S, Abbruzzese A, Stiuso P: Oxidative stress and ERK $1 / 2$ phosphorylation as predictors of outcome in hepatocellular carcinoma patients treated with sorafenib plus octreotide LAR. Cell Death Dis 2011, 2:e150.

148. Casaril M, Corso F, Bassi A, Capra F, Gabrielli GB, Stanzial AM, Nicoli N, Corrocher R: Decreased activity of scavenger enzymes in human hepatocellular carcinoma, but not in liver metastases. Intl I Clin Lab Res 1994, 24:94-97.

149. Liaw KY, Lee PH, Wu FC, Tsai JS, Lin-Shiau SY: Zinc, copper, and superoxide dismutase in hepatocellular carcinoma. Am J Gastroenterol 1997, 9212:2260-2263.

150. Ngoka LCM: Dramatic down-regulation of oxidoreductases in human hepatocellular carcinoma hepG2 cells: proteomics and gene ontology unveiling new frontiers in cancer enzymology. Proteome Science 2008, 6:29.

151. Hussain SP, Hofseth $L$, Harris CC: Radical causes of cancer. Nat Rev Cancer 2003, 3:276-285.

152. De Maria N, Colantoni A, Fagiuoli S: Association between reactive oxygen species, disease activity in chronic hepatitis C. Free Radic Biol Med 1996, 21:291-295.

153. Coradini D, Speranza A: Histone deacetylase inhibitors for treatment of hepatocellular carcinoma. Acta Pharmacol Sin 2005, 26(9):1025-33.

154. Pathil A, Armeanu S, Venturelli S, Mascagni P, Weiss TS, Gregor M Lauer UM, Bitzer M: HDAC inhibitor treatment of hepatoma cells induces 
both TRAIL-independent apoptosis and restoration of sensitivity to TRAIL. Hepatology 2006, 43(3):425-34

155. Rubiolo JA, Mithieux G, Vega FV: Resveratrol protects primary rat hepatocytes against oxidative stress damage: activation of the Nrf2 transcription factor and augmented activities of antioxidant enzymes. Eur J Pharmacol 2008, 591:66-72.

156. Das S, Das DK: Anti-inflammatory responses of resveratrol. Inflamm Allergy Drug Target 2007, 6:168-73.

157. Bishayee A, Barnes KF, Bhatia D, Darvesh AS, Carroll RT: Resveratrol Suppresses Oxidative Stress and Inflammatory Response in Diethylnitrosamine-Initiated Rat Hepatocarcinogenesis. Cancer Prev Res (Phila) 2010, 3(6):753-63.

doi:10.1186/1479-5876-9-171

Cite this article as: Marra et al:: Molecular targets and oxidative stress biomarkers in hepatocellular carcinoma: an overview. Journal of Translational Medicine 2011 9:171.

\section{Submit your next manuscript to BioMed Central} and take full advantage of:

- Convenient online submission

- Thorough peer review

- No space constraints or color figure charges

- Immediate publication on acceptance

- Inclusion in PubMed, CAS, Scopus and Google Scholar

- Research which is freely available for redistribution

Submit your manuscript at www.biomedcentral.com/submit 